\title{
China in the liberal oil market order
}

ABSTRACT: In the early $21^{\text {st }}$ century, the USD 64,000 Question has been whether China is actually integrating into the liberal world order. In this paper I concentrate on one segment of that order: the oil market order. I question the argument that in the present century the oil market order has moved away from being "liberal capitalist" towards becoming "state-capitalist" as a consequence of the rise of China and Chinese preferences. I argue that China has neither changed nor has had the power to change the international oil market order. To demonstrate this, I evaluate China's behavior towards the three pillars of the liberal oil market order. The first pillar is the United States' role as the underwriter of the global oil supply. The US guarantees oil security mainly through its military presence in the Persian Gulf, the most important region for oil exports. The US also guarantees the security of sea lines of communication. The second pillar is the ownership structure of the oil industry, where state-owned and privately-owned companies coexist. The third pillar is the currency of the oil trade (the US dollar) and its market-driven pricing system. It replaced the system of OPEC-administered prices that existed between 1973 and 1988. Pricing power moved away from OPEC to the so-called "market". In the period 2000-2020, China did not challenge any of those three pillars. China may be a mercantilist power, but in the first two decades of the $21^{\text {st }}$ century it remained within the liberal oil market order.

KEYworDs: China, international oil order, liberal world order, oil

Corresponding Author: Rafał Ulatowski; e-mail: r.ulatowski@uw.edu.pl

${ }^{1}$ Faculty of Political Science and International Studies, University of Warsaw, Poland; ORCID iD: 0000-0003-0655-9940; e-mail: r.ulatowski@uw.edu.pl

2021. The Author(s). This is an open-access article distributed under the terms of the Creative Commons Attribution-ShareAlike International License (CC BY-SA 4.0, http://creativecommons.org/licenses/by-sa/4.0/), which permits use, distribution, and reproduction in any medium, provided that the Article is properly cited. 


\section{Introduction}

In the early $21^{\text {st }}$ century, the USD 64,000 Question has been whether China would integrate into the liberal world order created by the United States. While liberals argue in favor of this idea (Ikenberry 2008), realists are skeptical. They believe that a peaceful rise of China is impossible, that the United States will not accept a peer competitor, and that the United States and China will inevitably clash (Mearsheimer 2001). A third argument escapes this binary scenario. Alister Johnston (2019) suggests that there are, in fact, multiple orders in different domains rather than one liberal order dominated by the United States. China is supportive of some of these orders, unsupportive of others, and only partially supportive of still others.

In this paper, order is understood as "an organized group of international institutions that help govern the interactions among the member states" (Mearsheimer 2019). One of the orders showing the position of China towards the international liberal order is the oil market order. The aim of this paper is to analyze China's behavior towards the oil market order in the period 2000-2020, as well as China's impact on the transformation of that order.

States treat oil differently than they do other goods, for two reasons. Firstly, oil-derived products are crucial for states' material capabilities, and these in turn are decisive for national security. Oil and great power politics are tightly intertwined. Energy security is a prerequisite of national security. Secondly, unlike most other goods, where oil is produced is determined by geology. Almost half of the proved total global oil reserves are located in the Middle East, and the Middle Eastern countries are responsible for $1 / 3$ of global production (Glaser 2013; BP 2020). This special interrelation of strategic and economic aspects makes the oil market order an interesting case study.

The rise of China and its well-developed energy diplomacy has been frequently seen as a game changer in the oil market. The revival of resource nationalism and the rise of state capitalism have been seen as a basis for a transformation from a "liberal capitalist" towards a "state-capitalist" order. This argument is based on an observed refusal by China and many oil-producing emerging economies to install a liberal economic system. In a "state-capitalist" order, it is not the markets but strategic considerations that are crucial to the international flow of commodities (Dannreuther 2015; Ostrowski 2015; Ziegler and Menon 2014; Christoffersen 2016; Lind and Press 2018).

The argument about the oil market's transformation from a "liberal capitalist" towards a "state-capitalist" order has significant weaknesses. Firstly, the oil market was always far from perfect, with competition hampered by state intervention such as the OPEC production restrictions and the United States' ban of oil exports between 1975 and 2015 (The Economist 2015). Secondly, the oil market features a complex interplay of strategic and market considerations. The alleged shift from "liberal-capitalist" towards "state-capitalist" behavior in the oil trade and investments really concerns only on market ideology. But the ideology of certain market participants is not enough to change the market order. Thirdly, that argument completely neglects the role of the United States in the oil market, which is closely connected with US hegemony (Bromley 1991; Stokes and Raphael 2010). 
I argue that the oil market order is a structure built on three pillars. I define these, and then evaluate China's policy towards each of them to find out whether the oil market order has actually changed. The analysis also provides some indication about the possible future development of oil market order in view of the growing competition between the United States and China.

This study argues that China has neither changed nor has had the power to change the international oil order. China may be a mercantilist power, but in the first two decades of the $21^{\text {st }}$ century it remained within the liberal oil market order.

\section{Material and methods}

To discuss China's impact on the liberal oil market order, I first discuss the three pillars of that order. I then evaluate China's behavior toward those pillars, based on the academic literature, statements made by Chinese officials, and statistical data from the International Energy Agency, the U.S. Energy Information Administration, OPEC, and BP.

The first pillar is the United States' role as an underwriter of the global oil supply. The United States guarantees oil security mainly through its military presence in the Persian Gulf, the most important region for oil exports. The US security guarantees cover the petro-monarchies of the Middle East, with Saudi Arabia foremost among them. In 1980, the Carter Doctrine was introduced. It designated the Persian Gulf as a vital area for the national interests of the United States, and later, military engagement in the region developed (Carter 1980). An affirmation of how the Carter Doctrine worked was the liberation of Kuwait in 1991.

The United States also guarantees the security of sea lines of communication (SLOC) and key transit points (choke points) that allow oil to be distributed globally. This guarantee is available to all countries of the world. It is "non-excludable" and "non-rival", meaning that greater consumption of this security by one country does not limit the amount of security available to others. The United States provides a public good, and other countries have a strong incentive to let America do so, because they cannot be forced to pay for the current arrangement. Due to the integrated nature of the oil market, the energy security of one country cannot be disaggregated from the energy security of other countries (Noël 2014).

The consequence is that the "liberal oil market" is a positive-sum market order. It allows all countries to integrate into the system and enables all interested states to sell or buy oil. Also, potential challengers of the United States are included in the system (from the US perspective, in order to pacify them). In this way, the order supports American hegemony while benefiting other powers, as well (Stokes and Raphael 2010). Assessments of how much it costs the United States to secure the oil market vary substantially, ranging from USD 13 billion to 143 billion annually (Crane et al. 2009).

Although relying on the US SLOC security guarantee may be cheapen inexpensive and comfortable strategy in peacetime, it can quickly lead to vulnerability during a conflict. The United 
States has the potential to coerce other countries to do its bidding by limiting or blocking oil shipments to or from hostile countries (Hughes and Long 2015; Kelanic 2016).

The second pillar is the ownership structure of the oil industry. In almost all countries of the world (the United States being the most important exception), subsoil resources are owned by the state, not private landowners. The exploration of those resources may be entrusted to a national oil company (NOC) or to private entities that gain access to oil through various kinds of contracts with the state. The ownership structure of the oil industry is a consequence of two groups of factors. The first one is the dominant economic ideology. Since the fall of the USSR and of the communist bloc, capitalism in its different varieties has dominated the global economy, with the liberal market economy enjoying its heyday during the 1990s, and state capitalism rising in importance in the early 2000s (Bremmer 2009). In states favoring the liberal market economy private companies tend to dominate the oil sector, while NOCs tend to dominate the sector in countries favoring state capitalism. The second group of factors include economic and technological issues. Rich countries with advanced technologies and favorable geology are less dependent on foreign investments, while low-income countries that are highly dependent on oil income face the dilemma of either allowing foreign investors to develop their resources or not seeing them developed at all (Bremmer and Johnston 2009).

In the oil market order that has emerged since the mid-1980s, some producing countries partially reopened their oil sectors to private (mainly foreign) investments. Different forms of cooperation between the public and private sectors emerged. The cash-strapped governments of oil-rich countries welcomed foreign investors in order to revive their local oil sectors. Only some countries of the Middle East kept their (upstream) oil industries under full state control; Saudi Arabia and Kuwait are prime examples of this. Many oil companies were privatized. In the 1990s, the interests of oil-producing and oil-importing countries converged somewhat. With the oil industry increasingly driven by technology, international oil companies (IOCs) continue to hold the lead in terms of technology and the development of geologically difficult fields (Claes 2018). IEA data show that in 2018 NOCs controlled $56 \%$ and INOCs $9.7 \%$ of global reserves. Independents controlled only $22 \%$ of reserves and majors (IOCs) $12.3 \%$ (IEA 2020a).

Despite the partial opening up of the oil sector to private investors, the United States did not succeed in reversing the wave of nationalization of the 1970s. In the 30 years of coexistence of IOCs and NOCs, different models for managing those companies and different levels of state control over them have been identified. There is a continuum from NOCs totally controlled by the governments of their country of origin, to NOCs highly independent of their governments, to IOCs that have high obligation to their country of origin, to IOCs independent of the government of their home country. Additionally, a group of "mixed" companies has emerged, where the state coexists as a shareholder along with private entities (Seznac 2012).

The third pillar of the market order is the currency of the oil trade and the oil pricing mechanism.

Here, the most important aspects are oil price denomination, invoicing, and the settlement currency. In the $20^{\text {th }}$ century, a relationship was observed between the internationalization of the currency (the US Dollar) and the rise of global oil use. For pricing commodities, only an international currency, or key currencies, are used. In the last quarter of the $20^{\text {th }}$ century, the US 
dollar dominated transactions in oil and petroleum products. Earlier, these had been made in at least two currencies: the US dollar and sterling. Barry Eichengreen, Livia Chiţu and Arnaud Mehl (2014) question the "conventional wisdom" which states "that network effects are strong in markets for homogenous goods, leading to the dominance of one settlement currency in such markets". These authors argue that, before and after World War II, payments in European countries for oil were equally split between the US dollar and other currencies, mainly sterling. Historically, royalty payments were also received by host countries mainly in US dollars, but also in sterling. Over time, as contracts expired and were replaced by new agreements between host countries and companies, sterling was replaced by the US dollar.

Although since the 1970s producers have at times wanted to diversify the currencies in which oil is traded, in the early 21 st century there were few exceptions from the use of the US dollar on the oil market (Eichengreen et al. 2014). The dominance of one currency in the oil trade should not be taken for granted. "That several national currencies could simultaneously play a role in international oil settlements suggests that a shift from the current dollar-based system toward a multipolar system in the period ahead is not impossible" (Eichengreen et al. 2014). But such a shift would have enormous consequences for the United States. Trading oil in US dollars and the financial investments of oil exporters in the US financial market have helped to finance the trade deficit of the United States in the last half century. Oil exporters supported the US dollar as an international currency (Woertz 2012). The dominance of the US dollar in the international oil trade gives the United States an economic and strategic advantage over its rivals.

Another aspect is oil price formation. In 1986-1988, a market-related pricing system was adopted in response to the increasing diversity of producers and consumers. It replaced the system of OPEC-administered prices that existed between 1973 and 1988. Pricing power moved away from OPEC to the so-called "market" (Hughes and Long 2015; Fattouh 2011).

The physical delivery of oil is secured either through the spot market or long-term contracts. A central feature of the oil pricing system is "physical" benchmarks. The most important of these are the West Texas Intermediate (WTI), Dated Brent, and Dubai-Oman. They are used to price cargos in spot transactions and long-term contracts. Also, the financial layers that surround the physical benchmarks are frequently used. Whereas the Dubai benchmark is mainly used to price mid-sour oil and Middle Eastern supplies, the WTI is used to price oil in America, and Brent has global relevance (Fattouh 2011). The significance of the physical benchmarks and the paper markets built around them is rooted in the global nature of the oil market (Adelman 1984).

\section{China and the first pillar}

The position of China towards the first pillar of the competitive oil market is ambiguous. The modernization of China's naval forces is well documented, and clearly one of its major goals is to secure SLOCs that are vital for China. Its naval forces have developed in an unpreceden- 
ted manner, with new types of ships introduced every year (Ross 2009). China is consistently worried about SLOC security, and about US dominance at sea. In November 2012, China's then-President Hu Jintao declared before the $18^{\text {th }}$ Congress of the Chinese Communist Party (CCP) that China should enhance its "capacity for exploiting marine resources, develop the marine economy, protect the marine ecological environment, resolutely safeguard China's maritime rights and interests, and build China into a maritime power". His successor Xi Jinping sees maritime power as an essential element of "China's Dream". Since the 1990s, China has succeeded in transforming its navy from a mostly coastal force to a blue water navy (Murphy and Roberts 2018). According to Xi Jinping, China will "speed up its preparation for any potential military conflict in the water areas and islands in regions like the Taiwan Strait and the South and East China Seas" (Everington 2020). In 2015, China passed a new security law giving the PLA the task of protecting the country's "overseas interests" (Hiim and Stenslie 2019).

As long as the oil market works and states have access to it, oil supplies are secure. But in the face of a lack of a higher authority, states have to prepare for the worst. To be cut off by an adversary when oil is needed during a war would be such a case, and China must certainly be aware that the United States has frequently targeted the oil sector of unfriendly countries to keep them in line. This strategy has also been discussed in relation to China (Mirski 2013; Cunningham 2020). Most Chinese analysts see a danger in China's dependence on the SLOCs controlled by the United States (Ross 2009; Erickson and Goldstein 2009).

Dependence on oil imports could be China's Achilles' heel (Mirski 2013). China is endeavoring to shift transport routes of its oil supply away from SLOCs towards its neighbors and towards oil imported by pipeline. Its cooperation with Russia, but also with Kazakhstan is especially important. As Table 1 shows, China's success in this area has been limited. Because China cannot significantly reduce oil imports by sea, it is trying to bypass two strategically sensitive areas: the Strait of Malacca and the South China Sea. That is why China invested in a pipeline connecting Kyaukphyu harbor in Myanmar with Kunming in Yunnan province. But although this was 'essentially completed' in early 2015, it started to pump oil only in April 2017 due to disputes between Myanmar and China about the taxes that China should pay. The Myanmar government demanded an additional 5\% tax additional to the previously agreed transit fee and pipeline duty, which jeopardized the economic efficiency of this route. Another pipeline having the same goal as the one through Myanmar is planned pipeline through Pakistan, from Gwadar to Kashgar. But it is suffering geographic, economic and security challenges that are making it a "geopolitical rather than geo-economic" project (Garlick 2018). As a Pentagon report to Congress argues: "China is particularly reliant on unimpeded SLOCs like the South China Sea and the Strait of Malacca to ensure hydrocarbon deliveries. In 2017, approximately 80 percent of China's oil imports and 13 percent of natural gas imports transited the South China Sea and Strait of Malacca" (Pentagon 2018).

China's development of a navy comparable in strength to the US Navy could be interpreted by the United States as a strategic challenge, and could also be costly for China economically. So, from the economic point of view, it makes perfect sense for China to rely on the security of the SLOCs provided by the United States and to enjoy having a cheap ride (Kennedy 2015). 
TABLE 1. China's crude oil imports by regions and countries, 2019

TABELA 1. Import ropy naftowej do Chin według regionów i krajów, 2019 r.

\begin{tabular}{|c|c|c|c|}
\hline Region & Share $[\%]$ & Country & Share $[\%]$ \\
\hline \multirow{7}{*}{ Middle East } & \multirow{7}{*}{44} & Saudi Arabia & 16 \\
\hline & & Iraq & 10 \\
\hline & & Oman & 7 \\
\hline & & Kuwait & 4 \\
\hline & & UAE & 3 \\
\hline & & Iran & 3 \\
\hline & & others & 1 \\
\hline \multirow{4}{*}{ Africa } & \multirow{4}{*}{18} & Angola & 9 \\
\hline & & Congo & 2 \\
\hline & & Libya & 2 \\
\hline & & others & 5 \\
\hline \multirow{2}{*}{ Former Soviet Union } & \multirow{2}{*}{16} & Russia & 15 \\
\hline & & others & 1 \\
\hline \multirow{4}{*}{ Western Hemisphere } & \multirow{4}{*}{15} & Brazil & 8 \\
\hline & & Columbia & 3 \\
\hline & & Venezuela & 2 \\
\hline & & others & 2 \\
\hline Asia-Pacific & 3 & & \\
\hline Europe & 3 & & \\
\hline
\end{tabular}

Source: EIA 2020.

But strategically, China has a strong incentive to develop its ability to control some SLOCs; its dependence on the security provided by the US Navy makes China vulnerable (Lei and Qinyu 2006; Lee 2005).

Also, any attempt by China to take on the role of guardian in the Persian Gulf would be interpreted by the United States as a threat to its national interests, as the Carter Doctrine suggests. That is why in recent decades China's strategy in the Middle East has been based on four pillars. Firstly, China aims to maintain good relations with all regional powers: Iran, Israel, Saudi Arabia; China has built no formal alliances. Secondly, China does not openly challenge the United States in the region. Thirdly, China's military presence in the region is limited, and is being developed from a position offshore. Its first overseas military base was opened in Djibouti; the base facilitates Chinese naval operations in both the Middle East and Africa. Fourthly, China prefers economic instruments over military instruments in foreign policy (Hiim and Stenslie 2019). 


\section{China and the second pillar}

When discussing the impact of China on the ownership structure of the oil industry, we have to start with the transformation of the Chinese economy. In 1978, China began to move its economy away from a centrally-planned economy towards a market economy. A hybrid system comprising state-owned enterprises in strategic sectors and different forms of collective enterprises and private enterprises have emerged in China in the last four decades. China has been classified as a state-capitalist economy (Bremmer 2009), and the oil sector is seen by the Chinese authorities as a strategic sector. Reformed during the last four decades, it is still under state control, and in consequence of those reforms, four companies: CNOOC, Sinopec, CNPC, and Sinochem, emerged as a leaders of the Chinese petroleum and petrochemical industry, dominating the whole supply chain. In China, the first upstream projects were opened up to private bidders in 2015 , and in the same year oil and gas import rights allowing non-state refiners ("teapots") to import oil directly were liberalized (Meidan 2016).

But, since China is a net oil importer, what is crucial is the behavior of Chinese enterprises abroad. Since the early 1990s, Chinese NOCs have experienced an incredible rise, from local companies with zero to little international experience to global players. China is interested in the liberal behavior of oil-rich countries and in their keeping reserves open to foreign investments, because this is China's only chance to acquire "equity oil".

China faces several risks to its energy security. The list includes oil supply risk, geopolitical risk, oil price volatility and exchange rate volatility (Daojiong 2006). As R. Kelanic argues, since WWI the oil dependence of some great powers has been used by their adversaries as a means of influencing them (Kelanic 2016). China has had the experience of living under sanctions more than once. The United States imposed sanctions on China in 1949, leaving the USSR as the only significant economic and military partner China could rely on (Leung 2011). But after the Soviet-Chinese split, this cooperation, too, was broken, causing serious economic problems for China (including in the energy sector) (Klinghoffer 1976).

Due to a mixture of strategic and economic considerations, the Chinese government sees equity investments in foreign oil as a method of mitigating supply risk, and since the $10^{\text {th }}$ Five-Year-Plan (2002-2005) has promoted the expansion of Chinese oil enterprises abroad in a more coherent way than in the 1990s. The expansion of Chinese NOCs has been associated with the growing role of state capitalism and government-to-government deals. China prefers strong government engagement to dependence on market forces (Lind and Press 2012).

Due to the super-cycle on the commodity markets in the early $21^{\text {st }}$ century, which resulted from a demand boom in the developing world, a wave of re-nationalization occurred in many oil-rich countries. This trend towards the state playing a bigger role may be seen as a reverse of the trend in the 1990s, when private oil companies received favorable conditions (Claes 2018).

After a decade of intensive investments, in 2011 the combined overseas oil and gas production of Chinese companies totaled $1.36 \mathrm{mboe} / \mathrm{d}$. In 2013, it reached $2.5 \mathrm{mboe} / \mathrm{d}$. In that same year, Chinese overseas oil production came mainly from Africa (26\%), the Middle East (24\%) 
and Eastern Europe and Central Asia (21\%). Also, smaller private companies have emerged as a force in China's oil and gas sector (Jiang and Ding 2014). In 2019, NOCs' production of overseas oil and gas reached $210 \mathrm{mtoe}$ (over $3.9 \mathrm{mboe} / \mathrm{d}$ ) (Ruan 2020). Chinese companies acquired assets through acquisitions, joint-ventures, mergers and new greenfield projects (Jiang and Ding 2014). But, the lengthening period of low oil prices that began in 2014 may have an adverse effect on production levels. Firstly, $60 \%$ of Chinese NOC assets are in high-risk countries; those risks can be political, economic or operational. Secondly, NOCs see their foreign assets as marginal compared to their assets in China, because they require higher investments per unit of produced oil. Some overseas investments located in high cost areas have already resulted in financial losses. At the same time, low oil prices offer financially strong Chinese companies opportunities to acquire blocks. They already declared interest in deep-water blocks in Brazil and South Africa (Ruan 2020).

As Chinese NOCs have frequently been seen as a state agent, a number of allegations has been made against them. Firstly, that they don't pay market prices for assets and overpay for political reasons, which renders private companies unable to compete against Chinese state-owned giants (Ebel 2009; Vermeer 2015). Secondly, that Chinese NOCs have a "perverse attitude toward risk" (Buckley et al. 2007) in their location decisions. Thirdly, that China may "lock up" oil reserves and enjoy preferential access to scarce resources (Silk and Malish 2006).

As Xiaoyi Mu has demonstrated, the behavior of Chinese companies has been ambiguous. They did not overpay for energy assets in the period 2001-2008, but overpaid significantly in the years 2009-2016 (mainly 2009-2013). The reason for this was not political pressure to provide energy security, but a mistaken assessment of the long-term condition of the market during the period of high oil prices (Mu 2020). It was believed that the new normal for oil prices was over USD 100/b, but since 2014 prices have fallen by half (BP 2020).

The second argument has also not been confirmed. Chinese NOCs' are becoming increasingly risk averse; they increasingly prefer to invest in countries with a strong rule of law, a low level of corruption, and a stable political economic and social system. Chinese oil companies are shifting their interest towards OECD countries (Chalmers and Mocker 2017).

Chinese companies have not locked up resources. Energy diplomacy clashes with market forces. The behavior of Chinese corporate leaders in the oil industry is characterized by contradictions and inconsistencies; these are rooted in the fact that NOCs act on a competitive market abroad but have strategic and social obligations back home (de Graaff 2014). Production from foreign assets is not automatically shipped to China. As oil produced in some countries and regions by Chinese companies mostly flows to China (for example, from Sudan), production from other regions and countries is sold on the international market to the highest bidder. Commercial motives strongly influence the decisions of Chinese oil companies producing abroad (Down 2007; Jiang and Sinton 2011). As they frequently hire oil traders, Chinese oil companies paradoxically encourage a liberal market structure (Economy and Levi 2014).

Despite the wave of investments China has made, it is still dependent on oil supplies from the Middle East, especially the oil monarchies, and is therefore affected by those countries' policies. Declarations of political proximity have not resulted in stable trade relations, as the example of 
Chinese-Iranian relations shows. The newest wave of US sanctions against Iran caused Chinese oil imports from Iran to drop from 8\% of China's overall imports in 2016 to about 3\% in 2019. In 2019, US sanctions against Venezuela caused imports from there to fall to $2 \%$ of overall Chinese imports (Table 1; EIA 2020). But China hopes that under the new administration of President Joe Biden those sanctions will be lifted, allowing Chinese-Iranian plans for cooperation to move forward (Lons and Nouwens 2021).

In the second decade of the $21^{\text {st }}$ century, oil supply growth has not been driven by NOCs, whose investments and energy diplomacy seem to have lost their momentum. Unconventional energy resources, such as shale oil, once damned by one of the greatest oil experts, Francis Parra, as a "misdirected" investment (Parra 2009), became a major force in the oil sector, transforming it within just a few years. In the 2000s, oil scarcity determined the discussion; now it is oil abundance. In 2010, US tight oil production was a nimble $0.4 \mathrm{mb} / \mathrm{d}$, and by 2019 it had reached $7.5 \mathrm{mb} / \mathrm{d}$ (IEA 2020b). Small and medium-sized innovative companies from the US, not state giants, charted the course for the development of the oil industry. China would like to follow the United States in developing unconventional oil and gas reserves, but it seems that, due to the differences in the two countries' economic structures, this will not be easy (Maugeri 2013).

\section{China and the third pillar}

The crucial elements in oil pricing are the method of pricing, the currency of the oil price denomination, invoicing, and settlement. The Chinese authorities are looking for growth in the international role of the RMB. One way to achieve that would be a rise in the role of the RMB on commodities markets, especially the oil market. The crucial question is whether the RMB can replace the USD as an oil pricing currency, or whether two or potentially more currencies can coexist.

The idea of the internationalization of the RMB started to be discussed in the aftermath of the 2008 financial crisis, when Chinese authorities started to deliberate on a reform of the international financial system. Zhou Xiaochuan (2009), Governor of the People's Bank of China, presented some reform proposals. It became clear that China no longer believed in the long-term stability of the US dollar. One of the immediate responses was a desire to diversify China's huge currency reserves kept in USD. As the co-chairman of the China Development Bank, Chen Yuan, told reporters, "everyone is saying we should go to the western markets to scoop up [underpriced assets]... I think we should not go to America's Wall Street, but should look more to places with natural and energy resources" (Anderlini 2009).

China has an interest in using its own currency rather than that of its main geopolitical competitor. The crude oil futures contract launched by the Shanghai International Exchange (INE) in 2018 is seen by some experts as an instrument for undermining the petrodollar. China would like to reduce the importance of the currently dominant benchmarks, and will shift part of the 
global oil trade to RMB. This should improve the liquidity of the RMB and promote its use in international trade. Further, it is argued that the growing importance of the RMB in the trade in oil and other commodities will push central banks and treasuries around the world to reduce their dollar holdings and build up their holdings of RMB. The acceptance of the RMB as a currency in which oil is traded would allow China to reduce its dollar holdings. Conditions for the RMB to challenge the USD would emerge (Merino and Graham 2018).

In recent decades, China has been discussing with its biggest suppliers how to switch from a USD-centric trade in oil towards other currencies. This idea, promoted by Russia for a number of years, has a good chance of coming to fruition - initially between China and Russia, as both countries face economic sanctions and economic pressure from the United States - though the authorities of Saudi Arabia (Watkins 2021) have also been showing signs of interest. China and Russia already settle a portion of their bilateral trade in their national currencies. In 2015, 90\% of their bilateral trade was settled in USD; in the first quarter of 2020 it was only $46 \%$. The ruble and the RMB were used in settling $24 \%$ of Russia-China bilateral trade in the first quarter of 2020. The sectors that most preferred to trade in RUB and RMB were commodity producers (especially oil and gas) and weapons producers - both sectors face sanctions from the United States (The Global Times 2020). At the same time, the euro made up an all-time high of $30 \%$ of settlements between Russia and China. This de-dollarization has been a priority for both countries since 2014, when they started expanding economic cooperation following Russia's conflict with the West over Crimea. Also, as the trade and tech war between China and the United States intensified, Beijing began to stand up for de-dollarization. In 2014, China and Russia signed a three-year currency swap, a deal extended in 2017. In 2019, during a visit to Russia by Xi Jinping, the two sides decided to replace the dollar with their national currencies in bilateral trade and to develop an alternative payment mechanism to SWIFT. As Alexey Maslov, director of the Institute of Far Eastern Studies at the Russian Academy of Science, agues: "Many expected that this would be a military alliance or a trading alliance, but now the alliance is moving more in the banking and financial direction, and that is what can guarantee independence for both countries". But other financial experts, such as Jeffrey Frankel, are skeptical, pointing to the advantages of the US dollar over all other currencies (Simes 2020). The first years of experience with the currency swap showed that, due to the "weak and disproportional" economic relations between the two countries, "a swap agreement cannot operate in full capacity as it does, for example, between China and the EU" (Spivak 2017). A decision taken by Russia and Saudi Arabia may upset the balance between the petro-yuan and the petro-dollar in favor of the former, since together these two countries account for one quarter of global oil exports. Exporters facing a geopolitical conflict with the United States, such as Venezuela and Iran, openly support the idea of trading more in RMB (Kamel and Wang 2019). As early as 2012, Iran's ambassador to the United Arab Emirates, Mohammed Reza Fayyad, confirmed that Iran priced its oil exports to China in RMB due to US sanctions (BBC 2012).

In the $21^{\text {st }}$ century, a number of challengers to the traditional benchmarks have emerged. One of them is China's International Energy Exchange (INE) oil futures contract. Many of these were created as government initiatives. Liz Bossley suggests that creating an oil benchmark cannot be 
easily engineered "by regulators or other authorities, although the Chinese yuan-based futures contract may be the exception that proves that rule" (Bossley 2018).

In the second decade of the $21^{\text {st }}$ century, the Chinese authorities came back to the idea of creating a futures contract for crude oil denominated in RMB. In 2012, Guo Shuqing, chairman of the China Securities Regulatory Commission, declared: "We must focus on establishing futures for crude and other commodities, to gradually strengthen China's pricing power in international markets" (Hook 2012). This means that China does not intend to reverse the financialization of the oil market, but wants to take a central position in that market.

Crude oil futures were launched by the Shanghai International Exchange (INE) on 26 March 2018. The new benchmark should better reflect the market dynamics in the Asia-Pacific region. They are denominated in RMB. Profits can be converted into US dollars. The contracts are physically settled, with seven grades to be delivered: six of them are Middle Eastern grades: Basrah Light, Dubai, Upper Zakum, Masila, Oman and Qatar Marine; the sevenths is Chinese Shengli. For the Chinese government, this step is an expression of China's transformation from price taker to price maker (Imsirovic 2020).

As this futures contract was being launched, several weaknesses were identified. Firstly, the grades of crude oil from the biggest suppliers to China: Russia, Saudi Arabia and Angola, were not included. Secondly, storage space is run by Chinese NOCs, whose tanks are spread along $2,700 \mathrm{~km}$ of the Chinese coastline, and an import license is required to import crude into China. Thirdly, government currency controls and interventions in the country's stock market have a discouraging effect on many investors, as do the low levels of reserves held in RMB by international banks, and exporters agreeing to deliver in exchange for RMB and later buy more in China, paying with RMB. Fourthly, China accounts for only 1/10 of global crude demand (Meidan 2018). Fifthly, the contract is beneficial mainly for Chinese refineries. It "allows Chinese refiners to buy crude at a fixed price (eliminating pricing risk), in yuan (eliminating currency exchange risk), and to purchase the exact volume they require (reducing cash flow risk) of high-quality crude oil (reducing margin risk). For small refiners, this is a huge benefit" (Merino and Graham 2018). It explains way Chinese private refiners and traders are the main force behind the INE contracts (Meidan and Imsirovic 2020). The only weakness from the point of view of refineries is that they don't know which out of seven crude grades they will receive. On the other hand, the producers/sellers bear all the risks and costs, especially those related to the freight/transport of crude oil (Merino and Graham 2018). The weaknesses of the contract "are likely to impede its international success. Its domestic success, on the other hand, is virtually ensured" (Liao et al. 2018). Chinese authorities are aware of these weaknesses and are determined to improve the contract. In 2020, substantial storage capacity was added. Capacity went up to 57 million barrels, allowing increased volumes of physical deliveries and encouraging foreign traders to deliver into the INE contract (Meidan and Imsirovic 2020).

Despite its weaknesses, the newly launched crude contract has attracted enormous interest. Two years after its creation, the INE is seeing volumes of trade in excess of those on the DME Exchange. The INE has become the third-largest oil exchange in the world (Meidan and Imsirovic 2020). As the People's Bank of China informs in the "2020 RMB Internationalization Re- 
port": "We expect more foreign traders to join the crude oil, iron ores and other commodities futures and uses the RMB more frequently in real commodity tradings" (People's Bank of China 2020).

\section{Conclusions}

In the period 2000-2020, China did not challenge the United States as an underwriter of the global oil supply. China followed a strategy of developing good relations with all Persian Gulf countries, regardless of their relations with the US. But China has not challenged US security strategy in the region, as the cases of the Iraq war and Iranian sanctions demonstrate. China has also not challenged US naval superiority. Rather, it has developed an energy security policy that aims to reduce China's dependence on US security guarantees. This strategy has had limited success, because China still has to import increasing amounts of oil by sea. This vulnerability, together with the increasing geopolitical competition between China and the US, is pushing China to develop military capabilities that could, in the medium or long terms, make it a serious rival of the US in terms of naval power.

Chinese oil diplomacy has proved effective in supporting local oil companies with gaining access to oil. Today, Chinese NOCs produce oil all over the world. But political considerations clash with market realities. Chinese NOCs have invested mostly in marginal assets, as mostly those were available on the market. When prices were rising, they profited. But the fall in oil prices resulted in losses on numerous projects. "Chinese equity oil" is mostly sold on the market to the highest bidder, and only a part of it is shipped back to China. The shale oil boom in the United States has put the long-term profitability of many projects into question by limiting long-term price prospects. Also, Chinese strategic alliances with oil exporters have not gone beyond the level of political declarations. Because the market is well supplied, China reduced its imports from Iran and Venezuela so as not to challenge the United States' sanctions policy, although it has never completely stopped importing oil from either of those two countries. Only in its relations with Russia is there a joint opposition towards the liberal world order that is underpinned with strong energy ties, although it may also be argued that China, the largest oil importer, and Russia, the second-largest oil exporter, are perfectly suited to each other as buyer and seller. The argument that strategic considerations in the Russian-Chinese oil trade have only a limited impact is supported by the fact that the closest ally of the United States in the Persian Gulf, Saudi Arabia, supplies as much oil to China as Russia does (OPEC 2020). Further, as Russia struggles to diversify its export markets and routes, China is struggling to diversify its import sources and routes. It would run against the interests of both countries for them to become overly dependent on each other.

Finally, by launching a new futures contract the Chinese authorities have demonstrated their commitment to the contemporary market order. The pricing method, with benchmarks at the 
heart of the formula, seems not to be in danger. The Chinese authorities have not presented any alternative to the current pricing method. Instead, they are trying to establish a futures contract traded in Shanghai as an international benchmark. Also, the use of the RMB is very limited, although it is gaining in importance. Crude oil futures traded on INE have a long road ahead to win global relevance and for the RMB to internationalize. Nevertheless, for some exporters, pricing their oil exports in RMB and basing the price on crude oil futures traded on the INE may be instrumental in promoting their oil exports to China. Countries indebted to China, or with substantial imports from China, may have a strong economic motivation to price their exports to China in RMB.

This study contributes to the discussion about the future of the world order. Although China did not challenge the oil market order or the role of the United States in this market in the period 2000-2020, it did lay the foundations for a possible transformation of the market order in the future. China is implementing its program of developing a blue water navy capable of safeguarding SLOCs, and it is developing strategic partnerships with oil-rich countries such as Russia and Iran. Finally, China is strengthening its role in oil pricing. The oil market seems to be a likely area of competition among the great powers.

\section{References}

Adelman, M.A. 1984. International Oil Agreements. The Energy Journal 5(3), pp. 1-9.

ANDERLINI, J. 2009. China to Deploy Foreign Reserves. Financial Times 21 July. [Online] http://www.ft. $\mathrm{com} / \mathrm{cms} / \mathrm{s} / 0 / \mathrm{b} 576 \mathrm{ec} 86-761 \mathrm{e}-11 \mathrm{de}-9 \mathrm{e} 59-00144$ feabdc0.html?nclick_check=1. [Accessed: 2021-07-07].

BBC 2012. China buying oil from Iran with yuan. 8 May. [Online] https://www.bbc.com/news/business-17988142. [Accessed: 2021-07-07].

BossLey, L. 2018. There Can(not) be Only One. OIES Forum (113), pp. 15-17.

BP 2020. Statistical Review. [Online] https://www.bp.com/content/dam/bp/business-sites/en/global/corporate/pdfs/energy-economics/statistical-review/bp-stats-review-2020-full-report.pdf. [Accessed: 2021-07-07].

Bremmer, I. and Johnston, R. 2009. The Rise and Fall of Resource Nationalism. Survival 51(2), pp. 149-158, DOI: 10.1080/00396330902860884.

Bremmer, I. 2009. State Capitalism Comes of Age. The End of the Free Market? Foreign Affairs 88(3), pp. $40-55$.

Bromley, S. 1991. American hegemony and world oil. University Park: Penn State Press, 316 pp.

Buckley et al. 2007 - Buckley, P.J., Clegg, L.J., Cross, A.R., Liu, X., Voss, H. and Zheng, P. 2007. The determinants of Chinese outward foreign direct investment. Journal of International Business Studies 38(4), pp. 499-518.

CARTER, J. 1980. Address by President Carter on the State of the Union Before a Joint Session of Congress. 23 January. [Online] https://history.state.gov/historicaldocuments/frus1977-80v01/d138. [Accessed: 2021-07-07].

Chalmers, A.W. and Mocker, S.T. 2017. The end of exceptionalism? Explaining Chinese National Oil Companies' overseas investments. Review of International Political Economy 24(1), pp. 119-143.

Christoffersen, G. 2016. The Role of China in Global Energy Governance. China Perspectives (2), pp. $15-24$. 
Claes, D.H. 2018. The Politics of Oil Controlling Resources. Governing Markets and Creating Political Conflicts. Cheltenham: Edward Elgar Publishing, 296 pp.

Crane et al. 2009 - Crane, K., Goldthau, A., Toman, M., Light, T., Johnson, S.E., Nader, A., Rabasa, A. and Dogo, H. 2009. Imported Oil and U.S. National Security. Santa Monica, Arlington, Pittsburgh: RAND Corporation, $126 \mathrm{pp}$.

Cunningham, F.S. 2020. The Maritime Rung on the Escalation Ladder: Naval Blockades in a US-China Conflict. Security Studies 29(4), pp. 730-768, DOI: 10.1080/09636412.2020.1811462.

DANNREuther, R. 2015. Energy security and shifting modes of governance. International Politics 52(4), pp. 466-483, DOI: 10.1057/ip.2015.4.

Daojiong, Z. 2006. China's Energy Security: Domestic and International Issues. Survival 48(1), pp. 179-190 , DOI: $10.1080 / 00396330600594322$.

DE GraAfF, N. 2014. Global networks and the two faces of Chinese national oil companies. Perspectives on Global Development and Technology 13(5-6), pp. 539-563. [Online] https://doi.org/10.1163/1569149712341317 [Accessed: 2021-05-09].

Down, E.S. 2007. The Fact and Fiction of Sino-African Energy Relations. China Security 3(2), pp. 42-68.

Ebel, R.E. 2009. Energy and Geopolitics in China. Mixing Oil and Politics. CSIS Report. [Online] https:// csis-website-prod.s3.amazonaws.com/s3fs-public/legacy_files/files/publication/091116_Ebel_EnergyGeoPolChina_Web.pdf. [Accessed: 2021-07-07].

Economy, E.C. and Levi, M. 2014. All Means Necessary: How China's Resource Quest is Changing the World. Oxford: Oxford University Press, 296 pp.

EIA 2020. China. [Online] https://www.eia.gov/international/analysis/country/CHN. [Accessed: 2021-07$-07]$.

Eichengreen et al. 2014 - Eichengreen, B., Chițu, L. and Mehl, A. 2014. Network effects, homogeneous goods and international currency choice: new evidence on oil markets from an older era. $E C B$ Working Paper Series No. 1651.

Erickson, A. and Goldstein, L. 2009. Gunboats for China's New 'Grand Canals'? Probing the Intersection of Beijing's Naval and Oil Security Policies. Naval War College Review 62(2), pp. 43-76.

Everington, K. 2020. Xi tells China's marines to 'prepare for war'. Taiwan News 14 October. [Online] https://www.taiwannews.com.tw/en/news/4029930. [Accessed: 2021-07-07].

Fattoun, B. 2011. An Anatomy of the Crude Oil Pricing System. Oxford: OIES, 83 pp.

GARLICK, J. 2018. Deconstructing the China-Pakistan Economic Corridor: Pipe Dreams Versus Geopolitical Realities.Journal of Contemporary China 27(112),pp.519-533,DOI: 10.1080/10670564.2018.1433483.

GLASER, Ch. L. 2013. How Oil Influences U.S. National Security. International Security 38(2), pp. 112-146.

Hirm, S.H. and Stenslie, S. 2019. China's Realism in the Middle East. Survival 61(6), pp. 153-166, DOI: $10.1080 / 00396338.2019 .1688578$.

Hook, L. 2012. Shanghai to launch crude futures contract. Financial Times. 9 February. [Online]. https:// www.ft.com/content/b2c6857c-5326-11e1-8aa1-00144feabdc0. [Accessed: 2021-07-07].

Hughes, L. and Long, A. 2015. Is There an Oil Weapon? Security Implications of Changes in the Structure of the International Oil Market. International Security 39(3), pp. 152-189, DOI: 10.1162/ISEC_a_00188.

IEA 2020a. The Oil and Gas Industry in Energy Transitions Insights from IEA analysis. [Online] https:// iea.blob.core.windows.net/assets/4315f4ed-5cb2-4264-b0ee-2054fd34c118/The_Oil_and_Gas_Industry_in_Energy_Transitions.pdf [Accessed: 2021-07-07].

IEA 2020b. US tight oil production, investment and free cash flow, 2010-2020. [Online] https://www.iea. org/data-and-statistics/charts/us-tight-oil-production-investment-and-free-cash-flow-2010-2020 [Accessed: 2021-07-07].

IKENBERRY, G.J. 2008. The Rise of China and the Future of the West: Can the Liberal System Survive? Foreign Affairs 87(1), pp. 23-37. 
Imsirovic, A. 2020. China and Asian oil benchmarks: Where next? OIES Forum (125), pp. 33-36.

JiAng, J. and Sinton, J. 2011. Overseas Investments By Chinese National Oil Companies. Assessing the drivers and impacts. Paris: IEA, $52 \mathrm{pp.}$

JIANG, J. and DING, Ch. 2014. Update on Overseas Investments by China's National Oil Companies. Achievements and Challenges since 2011. Paris: IEA, 49 pp.

Johnston, A.I. 2019. China in a World of Orders: Rethinking Compliance and Challenge in Beijing's International Relations. International Security 44(2), pp. 9-60, DOI: 10.1162/isec_a 00360.

Kamel, M. and Wang, H. 2019. Petro-RMB? The oil trade and the internationalization of the renminbi. International Affairs 95(5), pp. 1131-1148, DOI: 10.1093/ia/iiz169.

Kelanic, R.A. 2016. The Petroleum Paradox: Oil, Coercive Vulnerability, and Great Power Behavior. Security Studies 25(2), pp. 181-213, DOI: 10.1080/09636412.2016.1171966.

Kennedy, A.B. 2015. China and the Free-Rider Problem: Exploring the Case of Energy Security. Political Science Quarterly 130 (1), pp. 27-50, DOI: 10.1002/polq.12286.

KLinghoffer, A.J. 1976. Sino-Soviet Relations and the Politics of Oil. Asian Survey 16 (6), pp. 540-552.

Lee, P.K. 2005. China's Quest for Oil Security: Oil (Wars) in the Pipeline? Pacific Review 18(2), pp. 286-288, DOI: 10.1080/09512740500162949.

LeI, W. and QINYU, S. 2006. Will China Go to War over Oil? Far Eastern Economic Review 169(3), pp. $38-40$.

Leung, G.C.K. 2011. China's Energy Security: Perception and Reality. Energy Policy 39(3), pp. 1330-1337 , DOI: 10.1016/j.enpol.2010.12.005.

Liao et al. 2018 - Liao, T., Morse, E. and Yuen, A. 2018. China's New Crude Oil Benchmark. OIES Forum (113), pp. 34-37.

Lind, J. and Press, D.G. 2018. Markets or Mercantilism? How China Secures Its Energy Supplies. International Security 42(4), pp. 170-204, DOI: 10.1162/ISEC_a_00310.

Lons, C. and Nouwens, M. 2021. China-Iran deal: much ado about nothing? IISS. 7 April. [Online] https:// www.iiss.org/blogs/analysis/2021/04/china-iran-deal [Accessed: 2021-08-17].

Maugeri, L. 2013. The Shale Oil Boom: A U.S. Phenomenon. Cambridge, MA: Belfer Center for Science and International Affairs, $66 \mathrm{pp}$.

Mearsheimer, J.J. 2001. The Future of the American Pacifier. Foreign Affairs 80(5), pp. 46-61.

MeArsheimer, J.J. 2019. Bound to Fail: The Rise and Fall of the Liberal International Order. International Security 43(4), pp. 7-50, DOI: 10.1162/ISEC a 00342.

MeIDAn, M. 2016. The structure of China's oil industry: Past trends and future prospects. Oxford: OIES, $58 \mathrm{pp}$.

Meidan, M. 2018. China's Crude Awakening. OIES Forum (113), pp. 30-33.

Meidan, M. and Imsirovic, A. 2020. The Shanghai Oil Futures Contract and the Oil Demand Shock. Oxford: OIES, $11 \mathrm{pp}$.

Merino, A. and Graham, R. 2018. Petroyuan vs Petrodollar. OIES Forum (113), pp. 37-39.

MirSKI, S. 2013. Stranglehold: The Context, Conduct and Consequences of an American Naval Blockade of China. Journal of Strategic Studies 36(3), pp. 385-421, DOI: 10.1080/01402390.2012.743885.

Mu, X. 2020. Have the Chinese National Oil Companies Paid Too Much in Overseas Asset Acquisition? USAEE Working Paper No. 20-430.

Murphy, M. and RoberTs, P. 2018. The Reality of China's Maritime Capability. RUSI Journal 163(3), pp. 74-86, DOI: 10.1080/03071847.2018.1494352.

NoËL, P. 2014. Securing Middle East Oil. Adelphi Series 54 (447-448), pp. 247-256, DOI: 10.1080/19445571.2014.995949.

OPEC 2020. Annual Statistical Bulletin. [Online] https://asb.opec.org/ASB_Chapters.html[Accessed: 2021-07-07]. 
Ostrowski, W. 2015. State Capitalism and the Politics of Resources. [In:] Belyi, A.V. and Talus, K. eds. States and Markets in Hydrocarbon Sectors. London: Palgrave Macmillan, pp. 83-102.

Parra, F. 2009. Oil Politics: A Modern History of Petroleum. London: I.B. Tauris, 384 pp.

Pentagon 2018. Annual Report to Congress, Military and Security Developments Involving the People's Republic of China 2018. No. 8-0F67E5F.

People's Bank of China 2020. 2020 RMB Internationalization Report.

Ross, R.S. 2009. China's Naval Nationalism: Sources, Prospects, and the U.S. Response. International Security 34(2), pp. 46-81, DOI: 10.1162/isec.2009.34.2.46.

RuAN, Z. 2020. The Chinese majors' responses to the collapse in global oil prices and the COVID-19 pandemic: an upstream perspective. Oxford: OIES, $12 \mathrm{pp}$.

SEZnAC, J.-F. 2012. Politics of oil supply. National Oil Companies vs. International Oil Companies. [In:] Looney R. E. ed. Handbook of Oil Politics. Abingdon: Routledge, pp. 45-59.

Silk, M. and Malish, R. 2006. Are Chinese Companies Taking Over the World? Chicago Journal of International Law 7(1), pp. 105-131.

Simes, D. 2020. China and Russia ditch dollar in move towards 'financial alliance'. Financial Times 17 August. [Online] https://www.ft.com/content/8421b6a2-1dc6-4747-b2e9-1bbfb7277747. [Accessed: 2021-07-07].

SpIvak, V. 2017. Why a Russia-China Currency Swap Agreement Turned Out To Be a Damp Squib. Carnegie Moscow Center. 25 April. [Online] https://carnegie.ru/2017/04/25/why-Russia-China-currency -swap-agreement-turned-out-to-be-damp-squib-pub-69850. [Accessed: 2021-07-07].

Stokes, D. and Raphael, S.R. 2010. Global Energy Security and American Hegemony. Baltimore: Johns Hopkins University Press, 296 pp.

The Economist 2015. America lifts its ban on oil exports. 18 December. [Online] https://www.economist. com/finance-and-economics/2015/12/18/america-lifts-its-ban-on-oil-exports. [Accessed: 2021-07-07].

The Global Times 2020. Non-dollar trade settlements between China, Russia hit new high. 3 November. [Online]. https://www.globaltimes.cn/content/1205589.shtml. [Accessed: 2021-07-07].

Vermeer, E.B. 2015. The global expansion of Chinese oil companies: Political demands, profitability and risks. China Information 29(1), pp. 3-32, DOI: 10.1177/0920203X14566177.

Watkins, S. 2021. The Wider Ramifications of a China-Aramco Deal. Oilprice. 3 May. [Online] https:// oilprice.com/Energy/Energy-General/The-Wider-Ramifications-Of-A-China-Aramco-Deal.html. [Accessed: 2021-07-07].

Woertz, E. 2012. Oil, the Dollar, and the Stability of the International Financial System. [In:] Looney R. E. ed. Handbook of Oil Politics. Abingdon: Routledge, pp. 375-400.

Xiaochuan, Z. 2009. Reform the international monetary system. BIS Review 41, pp. 1-3.

Ziegler, Ch.E. and Menon, R. 2014. Neomercantilism and Great-Power Energy Competition in Central Asia and the Caspian. Strategic Studies Quarterly 8(2), pp. 17-41. 


\section{Chiny w liberalnym porządku rynku ropy naftowej}

\section{Streszczenie}

Od początku XXI wieku badacze stosunków międzynarodowych zastanawiają się, czy możliwe jest włączenie się Chin w liberalny porządek międzynarodowy. W tym artykule skoncentruję się na jednym segmencie tego porządku: porządku rynku ropy naftowej. Kwestionuję argument, że w obecnym stuleciu zmienił się on z „liberalnego kapitalizmu” w kierunku „kapitalizmu państwowego”, w wyniku wzrostu znaczenia Chin i chińskich preferencji w tym zakresie. Argumentuję, że Chiny nie zmieniły, ani nie były w stanie zmienić ładu na międzynarodowym rynku ropy. Aby to zademonstrować, analizie poddana została polityka Chin wobec trzech filarów liberalnego porządku rynku ropy naftowej. Pierwszym filarem jest rola Stanów Zjednoczonych jako gwaranta globalnej podaży ropy. Stany Zjednoczone gwarantują bezpieczeństwo naftowe głównie poprzez swoją militarną obecność w Zatoce Perskiej, najważniejszym regionie eksportu ropy, jak również bezpieczeństwo szlaków morskich. Drugim filarem jest struktura własnościowa przemysłu naftowego, gdzie współistnieją przedsiębiorstwa państwowe i prywatne. Trzeci filar to waluta handlu ropą (dolar amerykański) i rynkowy system ustalania cen. Zastąpił on istniejący w latach 1973-1988 system cen administrowanych przez OPEC. OPEC jest tylko jednym z podmiotów wpływających na poziom cen, który ustala rynek. W latach 2000-2020 Chiny nie kwestionowały żadnego z tych trzech filarów. Państwo to prowadzi politykę merkantylistyczną, ale w pierwszych dwóch dekadach XXI wieku funkcjonowało w ramach liberalnego porządku na rynku ropy naftowej.

SŁowa KLUCzowe: Chiny, międzynarodowy porządek rynku ropy naftowej, liberalny porządek międzynarodowy, ropa naftowa 